\title{
Balanced Fertilization Improves Fiber Yield and Quality of Winter Flax (Linum usitatissimum L.)
}

\author{
Feihu Liu* , Fei Li, Guanghui Du, Fu Xiao
}

Faculty of Agriculture, Yunnan University, Kunming, China.

Email: *hnplantbreed@gmail.com

Received March 22 ${ }^{\text {nd }}, 2011$; revised October 25 ${ }^{\text {th }}, 2012$; accepted November $3^{\text {rd }}, 2012$

\begin{abstract}
Winter fiber flax has been planted in a large area in Yunnan Province, the southwestern part of China, and other areas of the world, but little is known about the influence of fertilization on the fiber yield and quality. For that, a two-factor experiment in random block designed was carried out by specifying nitrogen $(\mathrm{N})$, phosphorus $(\mathrm{P})$ and potassium $(\mathrm{K})$ as factor A, boron (B), manganese (Mn), copper (Cu), zinc (Zn) and molybdenum (Mo) as factor B each in four levels and their complete combinations. With the increase of N, P and K fertilizers, the yields of long-fiber and total-fiber obviously increased resulting from the increased straw yield, although the portion of retted-stem in straw, contents of longfiber and total-fiber decreased. The fiber tensile strength and flexibility increased as well. The micronutrients application increased the yields of straw, long-fiber and total-fiber, but gave no influence to fiber content and the fiber qualities. Combinations of the macronutrients and micronutrients gave obvious influences to the yields of straw and fiber, contents of long-fiber and total-fiber, fiber fineness and tensile strength, but little influence to the fiber flexibility. The fertilizers formula A2B2, i.e. $\mathrm{N}-\mathrm{P}_{2} \mathrm{O}_{5}-\mathrm{K}_{2} \mathrm{O}$ 172.8, $28.8172 .8 \mathrm{~kg} / \mathrm{hm}^{2}$, Zn-Cu-B-M-Mo 2363, 1654, 236, 2363, 165 g/hm², was the best, yielding most in the straw, long-fiber and total-fiber, with synchronous improvement of the three quality indices.
\end{abstract}

Keywords: Fiber Quality; Fiber Yield; Macronutrients; Micronutrients; Proportional Fertilization; Winter Flax

\section{Introduction}

Fertilizers intensively influence the yield and quality of bast fiber crops. On summer flax, an appropriate amount of nitrogen promotes the growth, but too much nitrogen application causes an extravagant growth resulting in an excessively long and soft stem, and delayed maturity that decreases the phloem layer thickness, fiber content, fiber tensile strength and lodging-resistance of plants. However, nitrogen in combination with phosphorus $(\mathrm{P})$ and potassium (K) enhance the accumulation of cellulose in the fiber cell wall, increase the thickness of fiber cell wall, and improve the fiber tensile strength [1]. Arnold \& Malcolm [2] suggested that flax needs not only N, P and $\mathrm{K}$ nutrients, but also the micronutrients. They observed that application of B (boron) fertilizer obviously improved the absorption of other nutrients and increased the fiber content in flax stem. Moreover, application of Mo (molybdenum) and B in combination, with a proper level of N, P and K nutrients, improved fiber qualities such as fiber tensile strength, flexibility and fineness. The results were in agreement with the work of Holscher et al. [3].

"Corresponding author.
In China, technical reports about the influences of macronutrients to summer flax (that sown in spring or early summer) were well documented [4-6], and the influences of micronutrients to summer flax were also readable $[7,8]$.

As a new winter crop, winter flax has been produced in a large acreage during the last few years in the Southern China, especially in Yunnan Province, the southwest of China $[9,10]$. Winter flax is also planted in other areas such as the southeastern United States and the southeastern Australia [11,12]. Now the winter flax is an important complement to the crop and plays an important role in the flax fiber market of the world. However, the cultivation techniques, especially the influences of fertilization on the growth and development of winter flax were poorly documented [13]. Winter flax grows under conditions different from those of summer flax, how does fertilization influence the fiber yield and quality of winter flax? A two-factor experiment in random block design was carried out in this study by specifying $\mathrm{N}, \mathrm{P}, \mathrm{K}$ as factor $\mathrm{A}, \mathrm{B}, \mathrm{Mn}, \mathrm{Cu}, \mathrm{Zn}$, Mo as factor B in four levels and complete combinations. This work aimed at assessing the effects of balanced fertilization on the fiber yield 
and quality of winter flax, and suggests an optimal fertilization scheme for the winter flax cultivation. The result would be guidance for the local flax cultivation, as well be a reference for the winter flax cultivation in places beyond Yunnan Province.

\section{Materials and Methods}

\subsection{Field Experiment}

The experiment was carried out using a randomized twofactor block design, with $10 \mathrm{~m}^{2}$ plots and 3 replicates in a suburban field, with the foregoing crop maize. The seeds of cultivar Argos, 94\% of germination, treated with thiophanate methyl (mixed in 3:1000 of germicide to seed by weight) for seven days, were sown at 3000 fertile seeds per square meter. The field was managed following the local flax cultivation practice. The main nutrients in the field soil before experiment were tested as in Table 1.

Nitrogen ( $\mathrm{N}$, urea), phosphorus ( $\mathrm{P}$, normal calcium superphosphate) and potassium $\left(\mathrm{K}, \mathrm{K}_{2} \mathrm{SO}_{4}\right)$ were designnated as factor A, boron (B, $\left.\mathrm{Na}_{2} \mathrm{~B}_{4} \mathrm{O}_{7} \cdot 10 \mathrm{H}_{2} \mathrm{O}\right)$, manganese ( $\left.\mathrm{Mn}, \mathrm{MnSO}_{4} \cdot \mathrm{H}_{2} \mathrm{O}\right)$, copper $\left(\mathrm{Cu}, \mathrm{CuSO}_{4} \cdot 7 \mathrm{H}_{2} \mathrm{O}\right)$, zinc $\left(\mathrm{Zn}, \mathrm{ZnSO}_{4} \cdot 7 \mathrm{H}_{2} \mathrm{O}\right.$ ) and molybdenum (Mo, $\left(\mathrm{NH}_{4}\right)_{6} \mathrm{Mo}_{7}$ $\mathrm{O}_{24} \cdot 4 \mathrm{H}_{2} \mathrm{O}$ ) as factor B. Each factor was in four levels and complete combinations were conducted. The ratio of $\mathrm{N}: \mathrm{P}_{2} \mathrm{O}_{5}: \mathrm{K}_{2} \mathrm{O}$ was set at 1:0.2:1, Zn:Cu:B:Mn:Mo at 1:0.7:0.1:1:0.07 (Table 2), based on previous studies [7,14-16]. All of the micronutrients, $\mathrm{P}$ and $\mathrm{K}$ fertilizers, and $30 \%$ of $\mathrm{N}$ were mixed with the surface soil $(8 \mathrm{~cm}$ in depth) before sowing; the remained fertilizer was dressed at the beginning of the fast growing stage. The fertilizer dosages were given as in Table 2.

\subsection{Data Collection and Analysis}

Same data collection method was applied for all the experimental plots. All the plants were harvested and sun-dried for test of straw yield when the flax attained technical maturity. One fourth of the plants in each plot were tested for the portion of retted-stem in straw (sundried weight), contents of the total-fiber and long-fiber in the retted-stem. The total (or long) fiber yield was calculated as straw weight $\times$ portion of retted-stem $\times$ total (or long) fiber content, while portion of retted-stem (\%) = retted-stem weight $\div$ straw weight $\times 100$, total (or long) fiber content $(\%)=$ total (or long) fiber weight $\div$ rettedstem weight $\times 100$.

The long-fiber (scutched ribbon flax) was used to test the fiber qualities. According to China Guideline for Quality Test of Flax Fiber, an YG015 bundle-fiber tensile strength tester was used for testing the fiber tensile strength (Newton, N), and an YG962 pliability meter for the fiber flexibility (capacity of being flexed, $\mathrm{mm}$ ). The fiber fineness $(\mathrm{m} / \mathrm{g})$ was tested by a mid-part weight method-about $10 \mathrm{mg}$ fiber in $1 \mathrm{~cm}$ length, cut from the middle part of scotched ribbon flax that was combed by an 8-teeth-per-centimeter comb, was counted its number of the fiber bundles, and the connecting length in meters per gram then calculated. Each quality index was tested for thirty sub-samples from each treatment combination. The operation procedure of quality test is not debated here. All the statistical analysis was done sing STATISTICA 5.0 (StatSoft 1995), in a sequence of testing the normality of distribution and the homogeneity of variance, then doing a post hoc comparison.

\section{Results and Analysis}

\subsection{Effect of Fertilization on the Fiber Yield}

3.1.1. Effect of Fertilization Dosage on the Fiber Yield As the amount of macro elements increased, the yields of straw, total-fiber and long-fiber all increased, although the fiber content and portion of retted-stem decreased

Table 1. Nutrients in the soil before experiment.

\begin{tabular}{cccccccccccc}
\hline $\mathrm{pH}$ & Total $\mathrm{N}$ & Total $\mathrm{P}$ & Total $\mathrm{K}$ & Hydrolysable $\mathrm{N}$ & $\mathrm{P}_{2} \mathrm{O}_{5}$ & $\mathrm{~K}_{2} \mathrm{O}$ & $\mathrm{B}$ & $\mathrm{Mn}$ & $\mathrm{Cu}$ & $\mathrm{Zn}$ & $\mathrm{Mo}$ \\
\hline 5.39 & 2.4 & 1.6 & 13.9 & 205.45 & 14.96 & 260.20 & 0.61 & 33.83 & 44.56 & 9.16 & 0.12 \\
\hline
\end{tabular}

Total N, P and K measured by g/kg, others by $\mathrm{mg} / \mathrm{kg}$.

Table 2. Nutrients applied in the experiment.

\begin{tabular}{ccccccccccc}
\hline \multicolumn{1}{c}{ Factor A } & \multicolumn{7}{c}{ Factor B } \\
\hline Level & $\mathrm{N}$ & $\mathrm{P}_{2} \mathrm{O}_{5}$ & $\mathrm{~K}_{2} \mathrm{O}$ & Level & $\mathrm{Zn}$ & $\mathrm{Cu}$ & $\mathrm{B}$ & $\mathrm{Mn}$ & Mo \\
\hline A0 & 0 & 0 & 0 & B0 & 0 & 0 & 0 & 0 & 0 \\
A1 & 103.5 & 17.3 & 103.5 & B1 & 1688 & 1182 & 169 & 1688 & 118 \\
A2 & 172.8 & 28.8 & 172.8 & B2 & 2363 & 1654 & 236 & 2363 & 165 \\
A3 & 241.2 & 40.2 & 241.2 & B3 & 3038 & 2127 & 304 & 3038 & 213 \\
\hline
\end{tabular}

$\mathrm{N}, \mathrm{P}$ and $\mathrm{K}$ were measured by $\mathrm{kg} / \mathrm{hm}^{2}, \mathrm{Zn}, \mathrm{Cu}, \mathrm{B}, \mathrm{Mn}$ and $\mathrm{Mo}$ by g/hm². Urea contents $46.0 \%$ of N; Normal calcium superphosphate contents $18 \%$ of $\mathrm{P}_{2} \mathrm{O}_{5}$; $\mathrm{K}_{2} \mathrm{SO}_{4}$ contents $50 \%$ of $\mathrm{K}_{2} \mathrm{O}$; $\mathrm{ZnSO}_{4} \cdot 7 \mathrm{H}_{2} \mathrm{O}$ contents $22.5 \% \mathrm{Zn}$; $\mathrm{CuSO}_{4} \cdot 7 \mathrm{H}_{2} \mathrm{O}$ contents $22.4 \%$ of $\mathrm{Cu}$; $\mathrm{Na}_{2} \mathrm{~B}_{4} \mathrm{O}_{7} \cdot 10 \mathrm{H}_{2} \mathrm{O}$ contents $11.2 \%$ of B, $\mathrm{MnSO}_{4} \cdot \mathrm{H}_{2} \mathrm{O}$ contents $32.2 \%$ of $\mathrm{Mn},\left(\mathrm{NH}_{4}\right)_{6} \mathrm{Mo}_{7} \mathrm{O}_{24} \cdot 4 \mathrm{H}_{2} \mathrm{O}$ contents $53.8 \%$ of Mo. 
(Table 3). Under high level of macronutrients (A2, A3), flax yielded heavier straw, but had a lower portion of retted-stem and total (long) fiber contents. As for the fiber yield, A2 was the best fertilization level, yielded the heaviest total-fiber and long-fiber, as many as 2540.5 $\mathrm{kg} / \mathrm{hm}^{2}$ and $1310.5 \mathrm{~kg} / \mathrm{hm}^{2}$ that were significantly higher than A0 and A1 did (Table 3).

Increase of micronutrients also increased the straw yield of winter flax, but the effects were not as evident as macronutrients, while gave little influences to the portion of retted-stem and fiber contents. Considering the fiber yield, B2 was the best fertilization level, yielded the most straw and fiber that were significantly higher than B0 and B1 did (Table 4).

\subsubsection{Effect of Fertilizers Combination on the Fiber Yield}

Different combinations of macronutrients and micronutrients evidently affected the yields of straw and fiber, as well as the fiber contents (Table 5). The straw yields varied from 7536.7 to $11730.0 \mathrm{~kg} / \mathrm{hm}^{2}$ among the combinations. The total-fiber contents varied from $30.3 \%$ to $36.0 \%$, and long-fiber contents from $15.0 \%$ to $18.3 \%$. A0B2 had the highest total-fiber content and A0B3 had highest long-fiber content among all the combinations, while A0B1 gave very high contents of both total-fiber and long-fiber.

A3B2 produced the most straw as much as 11730.0 $\mathrm{kg} / \mathrm{hm}^{2}$, A2B1 had the best total-fiber yield up to 2640.8 $\mathrm{kg} / \mathrm{hm}^{2}$, while A2B2 yielded the heaviest long-fiber up to $1456.0 \mathrm{~kg} / \mathrm{hm}^{2}$ (Table 5). The influences of combined fertilization on the fiber yield and fiber contents were consistent quite well with that of macronutrients or micronutrients in single factor, which implied that application of $\mathrm{N}, \mathrm{P}, \mathrm{K}$ in combination with micronutrients could evidently increase the fiber yield of winter flax.

\subsection{Effect of Fertilization on the Fiber Quality}

\subsubsection{Effect of Fertilization Level on the Fiber Quality}

Increase of macronutrient fertilizers applied gave little influence to the fiber fineness of winter flax, but affected the flexibility and tensile strength (Table 6). On the other hand, different levels of micronutrients gave no influences to the flexibility and tensile strength, but a proper use of micronutrients e.g. B2, could improve the fiber fineness (Table 7).

\subsubsection{Effect of Fertilizers Combination on the Fiber Quality}

Macronutrients and micronutrients in different combinations evidently affected the fiber fineness and tensile strength, as well as the flexibility of winter flax. The fiber fineness varied from 277.0 to $413.0 \mathrm{~m} / \mathrm{g}$, tensile strength from 192.7 to $248.2 \mathrm{~N}$, and flexibility from 63.5 to $76.6 \mathrm{~mm}$ among the combinations. A3B2 gave the best fiber fineness and flexibility as many as $413.0 \mathrm{~m} / \mathrm{g}$ and $76.6 \mathrm{~mm}$, while A1B1 produced the strongest long-fiber, with tensile strength up to $248.2 \mathrm{~N}$ (Table 8). It was observed that the fiber fineness is in a good conformity with the flexibility, but not with the tensile strength. The results implied that fertilizers combination obviously affected the flax fiber quality, and the influence was greater to the tensile strength and fineness than to the flexibility (Table 8).

Table 3. Effects of macronutrients applied on the fiber yield and fiber contents.

\begin{tabular}{ccccccc}
\hline Level & Straw yield $\left(\mathrm{kg} / \mathrm{hm}^{2}\right)$ & $\begin{array}{c}\text { Portion of } \\
\text { retted-stem (\%) }\end{array}$ & $\begin{array}{c}\text { Total-fiber } \\
\text { content (\%) }\end{array}$ & $\begin{array}{c}\text { Long-fiber } \\
\text { content (\%) }\end{array}$ & $\begin{array}{c}\text { Total-fiber } \\
\text { yield }\left(\mathrm{kg} / \mathrm{hm}^{2}\right)\end{array}$ & $\begin{array}{c}\text { Long-fiber } \\
\text { yield }\left(\mathrm{kg} / \mathrm{hm}^{2}\right)\end{array}$ \\
\hline A0 & $8438.6 \mathrm{c}$ & $75.1 \mathrm{ab}$ & $34.3 \mathrm{a}$ & $17.5 \mathrm{a}$ & $2173.7 \mathrm{~b}$ & $1109.0 \mathrm{~b}$ \\
A1 & $9309.9 \mathrm{~b}$ & $75.5 \mathrm{a}$ & $32.8 \mathrm{ab}$ & $16.6 \mathrm{~b}$ & $2305.5 \mathrm{~b}$ & $1166.8 \mathrm{~b}$ \\
A2 & $10835.1 \mathrm{a}$ & $74.2 \mathrm{ab}$ & $31.6 \mathrm{bc}$ & $16.3 \mathrm{~b}$ & $2540.5 \mathrm{a}$ & $1310.5 \mathrm{a}$ \\
A3 & $11038.2 \mathrm{a}$ & $73.7 \mathrm{~b}$ & $30.8 \mathrm{c}$ & $16.5 \mathrm{~b}$ & $2505.6 \mathrm{a}$ & $1342.3 \mathrm{a}$ \\
\hline
\end{tabular}

A0 - A3 stand for the four levels of macronutrients applied in Table 2. Different letters show significant difference among the means in each column by Fisher LSD test at $\alpha=0.05$.

Table 4. Effects of micronutrients applied on the fiber yield and fiber contents.

\begin{tabular}{ccccccc}
\hline Level & $\begin{array}{c}\text { Straw yield } \\
\left(\mathrm{kg} / \mathrm{hm}^{2}\right)\end{array}$ & $\begin{array}{c}\text { Portion of Retted } \\
\text { stem }(\%)\end{array}$ & $\begin{array}{c}\text { Total-fiber content } \\
(\%)\end{array}$ & $\begin{array}{c}\text { Long-fiber content } \\
(\%)\end{array}$ & $\begin{array}{c}\text { Total-fiber yield } \\
\left(\mathrm{kg} / \mathrm{hm}^{2}\right)\end{array}$ & $\begin{array}{c}\text { Long-fiber yield } \\
\left(\mathrm{kg}^{2} / \mathrm{hm}^{2}\right)\end{array}$ \\
\hline B0 & $9291.0 \mathrm{c}$ & $74.4 \% \mathrm{a}$ & $32.3 \% \mathrm{a}$ & $16.6 \% \mathrm{a}$ & $2232.7 \mathrm{~b}$ & $1147.5 \mathrm{c}$ \\
B1 & $9777.4 \mathrm{~b}$ & $74.4 \% \mathrm{a}$ & $32.7 \% \mathrm{a}$ & $16.6 \% \mathrm{a}$ & $2378.7 \mathrm{ab}$ & $1207.5 \mathrm{bc}$ \\
B2 & $10542.4 \mathrm{a}$ & $74.6 \% \mathrm{a}$ & $32.4 \% \mathrm{a}$ & $16.6 \% \mathrm{a}$ & $2548.1 \mathrm{a}$ & $1305.5 \mathrm{a}$ \\
B3 & $10011.1 \mathrm{~b}$ & $75.2 \% \mathrm{a}$ & $32.0 \% \mathrm{a}$ & $16.8 \% \mathrm{a}$ & $2409.1 \mathrm{a}$ & $1264.8 \mathrm{ab}$ \\
\hline
\end{tabular}

B0 - B3 stand for the four levels of micronutrients applied in Table 2. Different letters show significant difference among the means in each column by Fisher LSD test at $\alpha=0.05$. 
Table 5. Effects of fertilizers combination on fiber yield and fiber content.

\begin{tabular}{|c|c|c|c|c|c|c|}
\hline Level & $\begin{array}{l}\text { Straw yield } \\
\left(\mathrm{kg} / \mathrm{hm}^{2}\right)\end{array}$ & $\begin{array}{l}\text { Retted stem } \\
\text { content (\%) }\end{array}$ & $\begin{array}{l}\text { Total-fiber } \\
\text { content (\%) }\end{array}$ & $\begin{array}{l}\text { Long-fiber } \\
\text { content (\%) }\end{array}$ & $\begin{array}{c}\text { Total-fiber } \\
\text { yield }\left(\mathrm{kg} / \mathrm{hm}^{2}\right)\end{array}$ & $\begin{array}{c}\text { Long-fiber } \\
\text { yield }\left(\mathrm{kg} / \mathrm{hm}^{2}\right)\end{array}$ \\
\hline A0B0 & 7536.7h & 75.1\%ab & $33.7 \%$ abc & $17.3 \%$ abc & 1897.1e & $974.8 \mathrm{i}$ \\
\hline A0B1 & 7895.6gh & $74.6 \% \mathrm{ab}$ & $35.0 \% a b$ & $17.7 \%$ ab & 2073.5de & 1032.3ghi \\
\hline A0B2 & 8566.1fg & 75.9\%ab & $36.0 \% a$ & 16.7\%abcd & 2357.0abcd & 1100.7fghi \\
\hline A0B3 & 9756.1de & 74.9\%ab & $32.3 \%$ abc & $18.3 \% a$ & 2365.9abcd & 1332.9abcd \\
\hline A1B0 & 8613.3fg & 74.3\%ab & $34.0 \% \mathrm{abc}$ & $15.7 \%$ cd & 2166.5cde & 1011.3hi \\
\hline A1B1 & 9208.3ef & $77.2 \% \mathrm{a}$ & $31.7 \%$ bc & 16.7\%abcd & 2256.2abcde & 1188.5defg \\
\hline A1B2 & $10426.7 \mathrm{~cd}$ & 75.3\%ab & $33.0 \% a b c$ & $15.7 \%$ cd & 2591.5ab & 1219.9cdef \\
\hline A1B3 & 8991.1ef & $75.2 \% a b$ & $32.7 \%$ abc & $17.0 \%$ abc & 2212.1bcde & 1149.5efgh \\
\hline A2B0 & 10398.3cd & 75.3\%ab & $30.7 \% c$ & 16.7\%abcd & 2408.5abcd & 1286.8bcde \\
\hline A2B1 & 10927.2abc & $73.3 \% \mathrm{~b}$ & $33.0 \% a b c$ & $16.3 \%$ bcd & 2640.8a & 1312.3abcde \\
\hline A2B2 & 11446.7ab & $73.5 \% \mathrm{~b}$ & $31.0 \% c$ & $17.3 \%$ abc & 2608.1ab & 1456.0a \\
\hline A2B3 & 10568.3bcd & $74.8 \% \mathrm{ab}$ & $32.3 \% \mathrm{abc}$ & $15.0 \% d$ & 2534.8abc & 1168.6defgh \\
\hline A3B0 & 10615.6bcd & $72.8 \% \mathrm{~b}$ & $31.0 \% \mathrm{c}$ & 16.7\%abcd & 2378.2abcd & 1277.9bcde \\
\hline A3B1 & 11078.3abc & $72.6 \% \mathrm{~b}$ & $31.0 \% \mathrm{c}$ & $15.7 \%$ cd & 2521.1abc & 1266.3cdef \\
\hline A3B2 & 11730.0a & 73.6\%b & $30.3 \% \mathrm{c}$ & $16.7 \%$ abcd & 2602.1ab & $1440.2 \mathrm{ab}$ \\
\hline A3B3 & $10782.9 b c$ & 75.9\%ab & $30.7 \% \mathrm{c}$ & $17.0 \% \mathrm{abc}$ & 2534.0abc & 1376.6abc \\
\hline Range & 7536.7 - 11730.0 & $72.6 \%-77.2 \%$ & $30.3 \%-36.0 \%$ & $15.0 \%-18.3 \%$ & $1897.1-2640.8$ & $974.8-1456.0$ \\
\hline Average & 9905.5 & $74.6 \%$ & $32.6 \%$ & $16.6 \%$ & 2384.2 & 1224.7 \\
\hline
\end{tabular}

A stands for macronutrients, B stands for micronutrients. A0B0 - A3B3 stand for the 16 combinations of four levels of macronutrients and micronutrients. Different letters show significant difference among the means in each column by Fisher LSD test at $\alpha=0.05$.

Table 6. Effects of macronutrients applied on the qualities of long-fiber.

\begin{tabular}{cccc}
\hline Level & Fineness (m/g) & Tensile strength (N) & Flexibility (mm) \\
\hline A0 & $331.0 \mathrm{a}$ & $210.0 \mathrm{~b}$ & $70.2 \mathrm{ab}$ \\
A1 & $325.6 \mathrm{a}$ & $228.2 \mathrm{a}$ & $64.9 \mathrm{~b}$ \\
A2 & $356.5 \mathrm{a}$ & $216.2 \mathrm{ab}$ & $67.6 \mathrm{ab}$ \\
A3 & $338.8 \mathrm{a}$ & $217.6 \mathrm{ab}$ & $72.3 \mathrm{a}$ \\
\hline
\end{tabular}

A0 - A3 stand for the four levels of macronutrients applied in Table 2. Different letters show significant difference among the means in each column by Fisher LSD test at $\alpha=0.05$.

Table 7. Effects of micronutrients applied on the qualities of long-fiber.

\begin{tabular}{cccc}
\hline Level & Fineness (m/g) & Tensile strength $(\mathrm{N})$ & Flexibility (mm) \\
\hline B0 & $334.3 \mathrm{~b}$ & $211.6 \mathrm{a}$ & $67.7 \mathrm{a}$ \\
B1 & $326.0 \mathrm{~b}$ & $218.5 \mathrm{a}$ & $68.6 \mathrm{a}$ \\
B2 & $375.0 \mathrm{a}$ & $222.4 \mathrm{a}$ & $71.2 \mathrm{a}$ \\
B3 & $316.6 \mathrm{~b}$ & $219.6 \mathrm{a}$ & $67.6 \mathrm{a}$ \\
\hline
\end{tabular}

B0 - B3 stand for the four levels of the micronutrients applied in Table 2 . Different letters show significant difference among the means in each column by Fisher LSD test at $\alpha=0.05$.

\section{Discussions}

Yagodin [17] reported that the straw yield of flax evidently increased, but the utilization coefficient of $\mathrm{N}$ fertilizer and fiber content decreased along with the increase of $\mathrm{N}$ fertilizer in a certain extent. Application of $\mathrm{N}$ and $\mathrm{K}$ fertilizers, especially an appropriate amount of $\mathrm{N}$ fertileizer could increase the fiber content and decrease the lignin content in fiber of summer flax [18]. Rational ap plication of $\mathrm{K}$ fertilizer could obviously increase fiber content and fiber tensile strength of flax, by which to improve the fiber quality [19].

In our experiment, the straw yield and fiber yield were both increased via a reasonable increase of fertilizers applied. However, it was observed that the fertilizers combination A3B2 yielded the most straw, while A2B1 and A2B2 yielded the most total-fiber and long-fiber. The fiber yield was decided not only by straw yield, but also by fiber content and the portion of retted-stem. Therefore, A3B2, although having a portion of rettedstem equal to that of A2B1 and A2B2, did not yield the most total-fiber and long-fiber due to its lowest content of total-fiber and relatively low content of long-fiber. A2B1 gave the highest total-fiber yield owing to its har- 
monious increases in straw yield, total-fiber content and portion of the retted-stem. The fertilizer efficiency (increase of fiber weight per fertilizer) could be deduced based on the amount of fertilizers applied and the yields of straw and fiber obtained, so that A2B1 could be the best fertilization scheme because of its highest total-fiber yield. Therefore, a fertilizers combination of producing the most straw maybe is not the best if assessed on the fiber yield and fertilizer efficiency.

On the other hand, the influences of fertilizers combination to the fiber qualities of winter flax were observed quite complicated. In addition, for the main three indices of flax fiber qualities, the fineness is well compatible with the flexibility, but is not compatible with the tensile strength. Therefore, it is important to obtain equilibrium or simultaneous improvement for the three indices. Considering the fiber yield and fiber quality, as well as the economic benefits of fertilizers, A2B2 in our study was the best and balanced fertilization scheme for its totalfiber yield near to the highest, the highest long-fiber yield, and the satisfied three quality indices, obtained from a relatively low input of fertilizers.

Table 8. Qualities of long-fiber as influenced by fertilizers combinations.

\begin{tabular}{cccc}
\hline $\begin{array}{c}\text { Fertilizers } \\
\text { combination }\end{array}$ & $\begin{array}{c}\text { Fineness } \\
(\mathrm{m} / \mathrm{g})\end{array}$ & $\begin{array}{c}\text { Tensile strength } \\
(\mathrm{N})\end{array}$ & $\begin{array}{c}\text { Flexibility } \\
(\mathrm{mm})\end{array}$ \\
\hline A0B0 & $319.9 \mathrm{bcde}$ & $224.4 \mathrm{abc}$ & $69.9 \mathrm{ab}$ \\
A0B1 & $285.6 \mathrm{de}$ & $207.0 \mathrm{bcd}$ & $72.2 \mathrm{ab}$ \\
A0B2 & $386.6 \mathrm{ab}$ & $216.1 \mathrm{bcd}$ & $71.8 \mathrm{ab}$ \\
A0B3 & $332.0 \mathrm{bcde}$ & $192.7 \mathrm{~d}$ & $67.1 \mathrm{ab}$ \\
A1B0 & $307.0 \mathrm{cde}$ & $215.3 \mathrm{bcd}$ & $67.6 \mathrm{ab}$ \\
A1B1 & $357.9 \mathrm{abc}$ & $248.2 \mathrm{a}$ & $63.5 \mathrm{~b}$ \\
A1B2 & $330.0 \mathrm{bcde}$ & $218.1 \mathrm{abcd}$ & $64.7 \mathrm{~b}$ \\
A1B3 & $307.6 \mathrm{cde}$ & $231.4 \mathrm{ab}$ & $63.9 \mathrm{~b}$ \\
A2B0 & $354.9 \mathrm{abcd}$ & $194.1 \mathrm{~cd}$ & $66.4 \mathrm{ab}$ \\
A2B1 & $350.9 \mathrm{abcd}$ & $198.3 \mathrm{~cd}$ & $65.3 \mathrm{~b}$ \\
A2B2 & $370.5 \mathrm{abc}$ & $237.4 \mathrm{ab}$ & $71.9 \mathrm{ab}$ \\
A2B3 & $349.8 \mathrm{abcd}$ & $235.1 \mathrm{ab}$ & $66.7 \mathrm{ab}$ \\
A3B0 & $355.5 \mathrm{abcd}$ & $212.8 \mathrm{bcd}$ & $66.8 \mathrm{ab}$ \\
A3B1 & $309.5 \mathrm{cde}$ & $220.4 \mathrm{abcd}$ & $73.4 \mathrm{ab}$ \\
A3B2 & $413.0 \mathrm{a}$ & $218.2 \mathrm{abcd}$ & $76.6 \mathrm{a}$ \\
A3B3 & $277.0 \mathrm{e}$ & $219.1 \mathrm{abcd}$ & $72.6 \mathrm{ab}$ \\
Range & $277.0-413.0$ & $192.7-248.2$ & $63.5-76.6$ \\
Average & 338.0 & 218.0 & 68.8 \\
\hline
\end{tabular}

A stands for macronutrients, B stands for micronutrients. A0B0 - A3B3 stand for the 16 combinations of four levels of macronutrients and micronutrients. Different letters show significant difference among the means in each column by Fisher LSD test at $\alpha=0.05$.

\section{Conclusions}

1) Rational increasing the amount of macronutrients applied to winter flax could increase the yields of straw, total-fiber and long-fiber, but decrease the contents of total-fiber and long-fiber, and the portion of retted-stem as well (Table 3).

2) Rational increasing the amount of micronutrients could not only increase the yields of straw, total-fiber and long-fiber, but also keep the contents of total-fiber and long-fiber, and the portion of retted-stem on higher levels (Table 4).

3) Combined fertilization could very significantly increase the yields of straw, total-fiber and long-fiber, by $55.6 \%, 39.2 \%$ and $49.4 \%$ for the best fertilizers combinations over the worst ones (Table 5).

4) Separate application of macronutrients or micronutrients gave little influences to the fiber qualities (Tables 6 and 7), but the best fertilizers combinations could increase the fiber fineness, flexibility and tensile strength by $49.1 \%, 20.6 \%$ and $28.8 \%$ over the worst ones (Table 8), by which the fiber qualities were improved.

\section{Acknowledgements}

The authors thank the financial support from the key project (No. 2002NG06) sponsored by Yunnan Department of Science and Technology, Yunnan Province, China, and the project (No. 30971825) from the National Natural Science Foundation of China (NSFC).

\section{REFERENCES}

[1] S. M. Lv, "The Standard and Examination of Bast Fibers,” Fiber Branch of China Association for Standardization, Beijing, 1993, pp. 81-90.

[2] W. S. Arnold and E. S. Malcolm, "Formulation of Environmentally Sound Waste Mixtures for Land Application," Water, Air, and Soil Pollution, Vol. 152, No. 1-4, 2004, pp. 195-217. doi:10.1023/B:WATE.0000015357.03531.b1

[3] D. Holscher, R. F. Moller, M. Denich and H. Folste, “Nutrient Input-Output Budget of Shifting Agriculture in Eastern Amazoni,” Nutrient Cycling in Agroecosystems, Vol. 47, No. 1, 1997, pp. 49-57. doi:10.1007/BF01985718

[4] C. F. Li, M. Li and K. R. Wang, "The Mechanism of Potassium Influencing the Yield and Quality of Fiber Flax," Journal of Northeast Agricultural University, Vol. 29, No. 1, 1998, pp. 21-26.

[5] Y. J. Li, "The Effect of N, P, Zn on Yield of Fiber Flax," Soils, Vol. 34, No. 5, 2002, pp. 286-288.

[6] T. H. Pan, Z. F. Zhang, D. Y. Li and Y. X. Zhou, "Study on Dry Matter Accumulation and Absorption and Distribution of N, P, K in Flax," China's Fiber Crops, Vol. 18, No. 1, 1996, pp. 34-36.

[7] F. Z. Guan, X. Y. Song and D. K. Wang, "Preliminary 
Research on the Influence of Micronutrients on Raw Stem Yield of Flax," China's Fiber Crops, Vol. 21, No. 1, 1999, pp. 37-40.

[8] L. Z. Xu and F. Z. Guan, "Influence of N, P, K on Fiber Cells Developing in Flax,” China's Fiber Crops, Vol. 22, No. 4, 2000, pp. 12-14.

[9] G. Y. Yang and Y. F. Lu, "Cultivation Technology for Fiber Flax in Yunnan Province,” Plant Fiber and Products, Vol. 25, No. 5, 2003, pp. 219-222.

[10] Q. N. Liu, M. L. Fu, X. Y. Wu, Z. L. Zhao and G. Du, "The Study of Relation among Straw Flax Yield, Density, Amount of Nitrogen and N, P, K Ratio,” Plant Fiber and Products, Vol. 28, No. 1, 2006, pp. 29-32.

[11] R. Dodd, J. Foulk and D. Akin, "Flax as a Winter Crop in the Southeastern United States," Proceedings of 58th Flax Institute of United States, North Dakota State University, Fargo, 2000, pp. 192-201.

[12] S. N. Lisson and N. J. Mendham, “Agronomic Studies of Flax (Linum usitatissimum L.) in South-Eastern Australia," Australian Journal of Experimental Agriculture, Vol. 40, No. 8, 2000, pp. 1101-1112. doi:10.1071/EA00059

[13] Z. X. Cheng, "Winter Flax Cultivation Technology," China Agro-Technology Extension, No. 1, 2004, p. 32.
[14] D. J. Reuter and J. B. Robinson, "Plant Analysis, an Interpretation Manual,” 2nd Edition, CSIRO Publishing, Collingwood, 1997, pp. 152-159.

[15] J. Z. Wan and X. C. Zhang, "The Cultivation and Processing of Fiber Flax,” China Agricultural Press, Beijing, 1998, pp. 9-14.

[16] S. H. Wang, X. F. Yang, C. H. Li, J. Q. He, Y. F. Chen and S. L. Yang, "Research on the Mathematic Model of Comprehensive Agricultural Measures for High Yield of Flax,” Plant Fiber and Products, Vol. 25, No. 1, 2003, pp. 14-21.

[17] B. Yagodin, "Utilization of Nitrogen by Fiber Flax Plants and Yield of Straw with Different Rates of Nitrogen Fertilizer," Izvestiya Timiryazevskoi Sel'skokhozyaistvennoi Akademii, Vol. 2, No. 1, 1991, pp. 89-94.

[18] X. Fu, M. Li and D. M. Li, "Research Advancement on Fiber Properties and Their Relationship with Yield and Quality of Flax,” Plant Fiber and Products, Vol. 26, No. 2, 2004, pp. 60-64.

[19] C. F. Li, M. Li, J. H. Liu and J. Jiang, "The Effect of Potassium on Flax Fiber Yield and Quality,” Heilongjiang Textile, No. 3, 1996, pp. 33-34. 